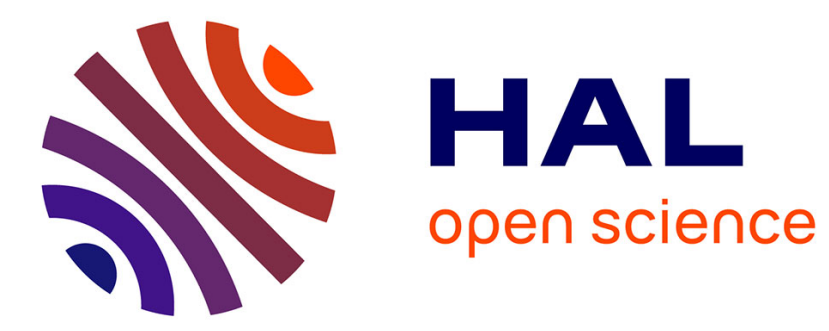

\title{
Sustaining the sequestration efficiency of the European forest sector
}

Aude Valade, Valentin Bellassen, Claire Magand, Sebastiaan Luyssaert

\section{To cite this version:}

Aude Valade, Valentin Bellassen, Claire Magand, Sebastiaan Luyssaert. Sustaining the sequestration efficiency of the European forest sector. Forest Ecology and Management, 2017, 405, pp.44-55. 10.1016/j.foreco.2017.09.009 . hal-01675305

\section{HAL Id: hal-01675305 https://hal.sorbonne-universite.fr/hal-01675305}

Submitted on 4 Jan 2018

HAL is a multi-disciplinary open access archive for the deposit and dissemination of scientific research documents, whether they are published or not. The documents may come from teaching and research institutions in France or abroad, or from public or private research centers.
L'archive ouverte pluridisciplinaire HAL, est destinée au dépôt et à la diffusion de documents scientifiques de niveau recherche, publiés ou non, émanant des établissements d'enseignement et de recherche français ou étrangers, des laboratoires publics ou privés. 


\title{
Sustaining the sequestration efficiency of the European forest sector
}

\author{
Aude Valade $^{\mathrm{a}, *}$, Valentin Bellassen ${ }^{\mathrm{b}}$, Claire Magand ${ }^{\mathrm{a}}$, Sebastiaan Luyssaert ${ }^{\mathrm{c}}$ \\ a Institut Pierre Simon Laplace (IPSL), CNRS-UPMC, Paris, France \\ b CESAER, AgroSup Dijon, INRA, Univ. Bourgogne Franche-Comté, F-21000 Dijon, France \\ c Department of Ecological Sciences, VU University Amsterdam, Amsterdam, The Netherlands
}

\section{A R T I C L E I N F O}

\section{Keywords:}

Forest

Wood

Sequestration efficiency

Climate change

Substitution

Residues

Sensitivity

Uncertainty

Model

Carbon balance

\begin{abstract}
A B S T R A C T
The optimal forest management strategies for mitigating climate change are hotly debated during political negotiations, because afforestation and forest management can increase atmospheric $\mathrm{CO}_{2}$ removal, and the wood produced can provide a substitute for fossil fuel. Studies quantifying the carbon balance of the forest sector apply a wide variety of management and wood-use scenarios. Some model studies include future climate change effects on forest growth, but others ignore them. Here, a conceptual empirical model of sequestration efficiency, the fraction of net primary production stored in the biosphere and anthroposhere, simulates European forest carbon pools and fluxes. The sensitivity of the sequestration efficiency of European forests was quantified by varying model parameters along the forest growth and wood transformation chain: environment and climate change, harvest intensity, rotation length, fraction of harvest residues left on site and substitution efficiency. Irrespective of the evolution of the sink, the forest sector as a whole remains a net carbon absorber in $99 \%$ of the simulations at a time horizon of 100 years, even if in $25 \%$ of the simulations the forests themselves become sources. However, if the goal is to enhance the current sequestration efficiency to mitigate emissions, only in $25 \%$ of the simulations the sink efficiency was found to be enhanced. If the current sink were to reverse to a source, no management action or change in wood use would result in an increase in the current forest sequestration efficiency. In all other cases, increasing harvest levels would lead to an increase in forest sector carbon emissions, highlighting the pivotal role of the baseline used to set the emission reduction targets. Our results show that the uncertainty on the response of European forest to climate change undermines the quest for a carbon-optimal management strategy. The uncertainty in whether climate change will maintain the current forest sink or turn it into a carbon source is largely overlooked in the debate over the best forest management strategy to reduce the growth of atmospheric $\mathrm{CO}_{2}$ concentration, yet it is large enough to change the merit order of different alternatives.
\end{abstract}

\section{Introduction}

Expectations of forests and forest management are high, especially in the context of climate change mitigation (UNFCCC, 2015). These expectations are based on the potential of: (a) afforestation, reduction of deforestation emissions and forest management to remove atmospheric $\mathrm{CO}_{2}$ through photosynthesis, (b) carbon stored in wood products to delay the release of harvested carbon into the atmosphere, and (c) substitution of fossil fuel by wood in energy production or by the replacement of energy-intensive materials. With $64 \%$ of the world's forests being managed (FAO, 2010) and an estimated global forest carbon sink of $2 \mathrm{Pg} \mathrm{C} \mathrm{yr}^{-1}$ (Pan et al., 2011), excluding tropical deforestation (Le Quéré et al., 2009), forests appear to live up to these expectations. As a result, the Paris agreement places forests at the heart of the carbon emissions mitigation initiatives with its articles 4 and 5 respectively stating the need to "reach a balance of anthropogenic emissions and removals in the 2nd half of the century" and to "conserve and enhance the sink" (UNFCCC, 2015).

A large body of research has been published focusing on evaluating and managing the potential of the forest sector to offset $\mathrm{CO}_{2}$ emission from fossil fuel burning. This work shows that increasing wood removal, while keeping all other parameters constant, whether realized through shorter rotation length (Kaipainen et al., 2004; Liski et al., 2001) or removal of stumps and slash (Strömgren et al., 2013), would increase the carbon emission of the forest sector in the first years following the treatment. Where wood products are used in place of more fossil-intensive energy or materials, wood usage leads to a (relative) reduction in carbon emission quantified through so-called substitution or displacement coefficients (Sathre and O'Connor, 2010). Even though the substitution effect was found to have a large impact on the wood-

\footnotetext{
* Corresponding author.

E-mail address: aude.valade@ipsl.jussieu.fr (A. Valade).
} 
products carbon balance (Fortin et al., 2012; Lundmark et al., 2014), the definition and use of substitution coefficients is subject to large uncertainties due to their dependence on methodological choices to define the characteristics of the industries, and the reference scenario (Hellweg and i Canals, 2014). Consequently, increased wood removals were reported either to reduce, at least in the long term (Lundmark et al., 2014; Marland and Schlamadinger, 1997; Perez-Garcia et al., 2007; Vanhala et al., 2013), or not reduce (Fortin et al., 2012; Hudiburg et al., 2011; Kallio et al., 2013; Sievänen et al., 2014) atmospheric $\mathrm{CO}_{2}$ concentration as substitution effects accumulate over time.

Wood removal, product use and energy substitution are all accounted for in recent studies on carbon management in the forest sector, however, the uncertainty surrounding the future evolution of the forest sink under climate change-changes in allocation of carbon to the short- and long-lived soil and biomass pools of the forest-and its interaction with management practices have mostly been ignored. It is often implicitly assumed that the forest sink tends towards zero when forest stands grow older than 100 years leading to carbon-neutral forest (Lippke et al., 2011), even though observational evidence does not lean in that direction (Lewis et al., 2009; Luyssaert et al., 2008). Some other studies assume that the current sink strength is maintained indefinitely, either implemented as a single average sink over the study area or, more refined, as a function of age (Hudiburg et al., 2011; Kallio et al., 2013; Lundmark et al., 2014; Pilli et al., 2017; Smyth et al., 2014) .

The recent forest sink has been attributed to changes in environmental conditions, with $\mathrm{CO}_{2}$ concentration, temperature patterns and nitrogen deposition all contributing to the observed acceleration in tree growth (Lewis et al., 2009; Magnani et al., 2007; McMahon et al., 2010; Solberg et al., 2009). For the European forests, changes in age structure and management practice (Nabuurs et al., 2003) were also found to play a role. Nevertheless, the importance of the drivers of the current sink likely differs for different regions in Europe (Bellassen et al., 2011). While $\mathrm{CO}_{2}$ fertilization has been projected to overtake nitrogen deposition as the main driver of the forest carbon sink in the future (Milne and Van Oijen, 2005), these projections are controversial because they disregard physiological constraints (de Boer et al., 2011), overlook the indirect effect of decreased tree longevity (Bugmann and Bigler, 2011) and do not account for the saturation of the $\mathrm{CO}_{2}$ effect due to nitrogen (Hungate et al., 2003; Norby et al., 2010) or phosphorus limitation.

Much of the controversy stems from the knowledge gap in how the different components of heterotrophic respiration will respond to climate change (Cox et al., 2000; Cramer et al., 2001; Subke and Bahn, 2010). Also, it is currently suspected that interannual variability and the role of disturbance will become major future players in driving the sink strength of temperate and boreal forest (Anderegg et al., 2013; Beck et al., 2011; Kurz et al., 2008; Lindroth et al., 2009; Zeng et al., 2009). As a result of this inadequate process understanding, an ensemble of state-of-the-art process-based models disagrees on the magnitude of the terrestrial carbon sink by 2100 , and even on its sign (Friedlingstein et al., 2014). Under the same emission scenarios some models predict the European forest will absorb up to $0.5 \mathrm{Pg} \mathrm{C} \mathrm{yr}^{-1}$, while others conclude it will become a source of $0.5 \mathrm{Pg} \mathrm{C} \mathrm{yr}^{-1}$ (Friedlingstein et al., 2014). Despite being the most advanced tools to integrate ecological and physical knowledge into a consistent numerical framework, the capability of process-based models is still limited in tackling the aforementioned issues because these models are rarely designed to explicitly simulate forest management, nitrogen dynamics, pest and disease hazards and extreme events all at the same time (Naudts et al., 2015). Regional-scale empirical models, for their part, include all the complexity of management strategies and forest types and structures but are constrained to short time horizons and often limited in their capacity to simulate the effects and feedbacks of climate change on forest growth and dynamics (Pilli et al., 2017).

Although all of the controls listed above have been extensively studied separately in almost two decades of carbon management research, it remains difficult to integrate the results of this research into a consistent framework (Bellassen and Luyssaert, 2014). The problem is that different studies make different assumptions and this hampers the comparison and generalization of the results. In this study, the main uncertainties in European forestry carbon management are analysed with the goal of quantifying their contributions to the overall carbon balance of the sector and of delimiting a "safe operational space" for carbon management. This safe operational space is defined as a combination of forest management and wood-use measures that should result in maintaining or increasing the overall forest sector carbon sequestration potential compared to today.

\section{Methods}

\subsection{Carbon sequestration efficiency}

The net carbon budget of the forest sector consists of the carbon sequestered in both the forest ecosystems and in wood-use chains either through storage or substitution. In ecosystems, the net carbon input is referred to as net primary production (NPP); here we assume NPP is equal to biomass production and focus on sequestration efficiency, which is defined as the ability of the ecosystem and wood use chain together to retain part of the incoming NPP. In Europe, temperate and boreal forests lose carbon through two major pathways: timber harvesting, and heterotrophic respiration $\left(R_{h}\right)$ (Luyssaert et al., 2010). The balance between carbon inputs and outputs is called the net biome production (NBP; (Chapin et al., 2006)). A positive NBP indicates the forest is a sink and thus accumulates carbon in the soil, litter and/or biomass, whereas a negative NBP indicates the ecosystem is a carbon source. Contrary to $R_{h}$, the carbon contained in the harvested wood is not immediately released back into the atmosphere-it can be stored in wood products. If it is stored in wood products, carbon is released at a decay rate that depends on the products' longevity. Furthermore, if the harvested wood is used to replace a more fossil fuel-intensive material or energy source, the substitution effect may come into play. Substitution may result in avoided emissions, which, for bookkeeping purposes, can be considered as a sink that should be included in the carbon budget of the forest sector. The carbon balance of the forest sector $\left(\Delta C_{\text {forest sector }}\right)$ can thus be formalized as:

$\Delta C_{\text {forest sector }}=N B P_{t}+H W P_{t}+S_{t}$

where $N B P_{t}, H W P_{t}$, and $S_{t}$ are the carbon input at time $t$, into the ecosystem, into the wood-product pool, and the avoided emissions through substitution respectively, all expressed in $\mathrm{g} \mathrm{C} \mathrm{m}^{-2} \mathrm{yr}^{-1}$. Likewise $\Delta C_{\text {forest sector }}$ can be written as a function of the overall NPP at time $t$ :

$\Delta C_{\text {forest sector }}=N P P_{t} \cdot\left(\frac{N B P_{t}+H W P_{t}+S_{t}}{N P P_{t}}\right)$

$\Delta C_{\text {forest sector }}=N P P_{t} . S E_{t}$

where $S E_{t}$ is the unitless sequestration efficiency of the forest sector and is calculated as:

$S E_{t}=\frac{N B P_{t}+H W P_{t}+S_{t}}{N P P_{t}}$

As shown in Eq. (2), the carbon balance of the total European forest sector can be calculated as the product of the total forest NPP over Europe and the sequestration efficiency for European forests. The sequestration efficiency of the forest sector represents the share of carbon sequestered in the forest sector per unit of NPP. In other words, if the sequestration efficiency equals 0.23 this implies that for each gram of carbon that has been used for biomass production in the forest ecosystem, $0.23 \mathrm{~g} C$ will be sequestered in the forest sector and thus did not end up in the atmosphere. This study focuses on quantifying the main drivers of the sequestration efficiency.

The advantage of this approach is that it separates the production, i.e., net primary production, from the efficiency of the production, i.e., sequestration efficiency. Such an approach stresses the fundamentally 
different effect of processes such as afforestation, deforestation, dieback, and changes in age-class structure that mainly affect the net primary production and processes such as rotation length, wood-use, substitution, heterotrophic respiration that mainly affect the sequestration efficiency.

\subsection{Carbon balance model}

Combining the carbon pools and fluxes of the forest sector in a simple empirical mass balance model enabled us to project the dynamics of the carbon budget (Fig. S1). Following Chapin et al. (2011), the annual carbon budget of an ecosystem for year $t$ was written as:

$\mathrm{NPP}_{\mathrm{t}}=\mathrm{D}_{\mathrm{t}}+\mathrm{H}_{\mathrm{t}}+\mathrm{R}_{\mathrm{h}, \mathrm{t}}+\mathrm{NBP}_{\mathrm{t}}$

Showing that NPP is consumed by stand-replacing natural disturbances $\left(D_{t}\right)$, appropriated by humans through harvest $\left(H_{t}\right)$, or leaves the ecosystem through annual total of heterotrophic respiration $\left(R_{h, t}\right)$. The remaining carbon is sequestered as NBP in the ecosystem: in the soil, the litter, the coarse woody debris and the living biomass (Chapin et al., 2006). The present study does not distinguish between the aboveand belowground components of NBP.

At each yearly time step $(t)$, the harvest and disturbance fluxes were first assigned their prescribed values. Total $R_{h}$ was then partitioned into its three main components: respiration from harvest debris decomposition, respiration from root and leaf decomposition, and respiration from free-living microbes (Bowden et al., 1993; Tang et al., 2005). Harvests and disturbances leave woody debris on site, of which a part will remain in the ecosystem as the recalcitrant fraction in the soil, its chemical and/or physical properties hampering decomposition by micro-organisms (De Deyn et al., 2008). The remainder of the debris is readily decomposed through heterotrophic respiration $\left(r_{\text {debris }}\right)$. Plant growth indirectly contributes to heterotrophic respiration through the production and subsequent decomposition of leaf and root litter (Raich and Nadelhoffer, 1989). This respiration component $\left(r_{\text {root-leaves }}\right)$ was assumed to be a constant fraction of NPP. Finally, the remaining part of $R_{h}\left(r_{e n v}\right)$ accounts for the respiration of the soil microbial community and depends upon many environmental factors (Tang et al., 2005). This $r_{e n v}$ component is particularly poorly understood (Jones et al., 2003; Subke and Bahn, 2010) and is the root cause of the uncertainty in the evolution of the future forest sink as it contains the effects of soil temperature and moisture, nutrient availability and soil microbiology on soil respiration (Mack et al., 2004; Singh et al., 2010). This environment-related fraction of $R_{h}$ is interpreted as the key driver of the uncertainty in the evolution of the forest carbon sink (NBP). The NBP was calculated as the carbon remaining after $H, D$ and $R_{h}$ fluxes had been evaluated. Changes in sink strength only affect other components of the carbon balance when respiration is too high to be sustained with the prescribed harvest level. In those cases harvest is reduced to a level that satisfies the respiration flux.

In the model, the forest sink is formalized through Eq. (4) and was completed by accounting for the carbon contained in the wood harvest. Disturbances were assumed to be salvage-logged (Lindenmayer and Noss, 2006; McIver et al., 2000). Therefore, both harvest (H) and postdisturbance salvage-logging (D) end-up in one of four wood-product pools each with a different lifetime and substitution potential (Eggers, 2002) (Table 2). The carbon contained in these wood-product pools follows an exponential decay function, where the decay rate depends on the expected lifetime of the pool:

$W P_{t}=W P_{t-1} \cdot e^{-\left(\frac{t-(t-1)}{\tau}\right)}$

where $W P_{t}$ denotes the carbon contained in the pool at time $t$, and $\tau$ is the expected lifetime of the wood products. Furthermore, emissions avoided through replacement of fossil-fuel-intensive products by wood were calculated for each time step (Table 2) and contributed to the sequestration efficiency given by Eq. (3).
$S_{t}=\frac{E_{f f}-E_{w}}{Q_{f f-}-Q_{w}} \cdot g H W P_{t}=s . g H W P_{t}$

where the $E_{f f}$ and $E_{w}$ refer to the emissions due to the provision of equivalent services respectively in fossil fuel-based and wood-based production systems, and $Q_{f f}$ and $Q_{w}$ refer to the quantity of wood used for the provision of equivalent services in a fossil fuel-based and woodbased production system, respectively, $g H W P_{t}$ is the gross number of units produced from harvest at time $t$. The term $\frac{E_{f f}-E_{w}}{Q_{f f}-Q_{w}}$ is the so-called substitution coefficient, $s$, reported in the literature for each category of wood product (long-lived, medium-lived, and biofuel wood products).

All other parameters being equal, changes in the fraction of residues left on site after harvest or salvage logging affect the amount of wood available for wood products, hence the storage of carbon and the substitution potential. A feedback on tree growth due to fertility losses or gains was not implemented because of a lack of empirical data on this process.

Increasing harvest levels by shortening rotation periods is often justified by an expected increase in biological production resulting from a shift of the age structure toward younger and potentially more productive forests. Although knowledge gaps persist in the mechanistic understanding of the driving processes, observations across a variety of forests confirms an age-dependency of NPP: stand-level NPP increases in the early stages, reaches a peak and then decreases as forests age (Ryan et al., 1997; Tang et al., 2014). In the model, the total NPP accounted for the age-effect by modulating total NPP as a response to harvest rate:

$\overline{N P P}=\alpha_{T} \cdot N P P$

where NPP is the observed average biomass production for European forests, $\overline{N P P}$ is the average biomass production adjusted for rotation length and $\alpha_{T}$ is the correction factor determined from the age-NPP relationships and extracted for rotation length $T$, or age-effect coefficient. If the imposed rotation length was not optimal for forest production, i.e., harvest before or after the culmination of the annual mean increment, the total NPP was reduced by an age-effect coefficient.

Note that the model design implies that all other parameters being equal, changes in harvest levels affect the amount of residue left on site (parameterized as a fraction of wood removal), of long-lived, mediumlived and short-lived harvested wood products (fixed fractions of the harvested wood for each category), and of substitution potential (directly calculated from wood-product pools).

Furthermore, the model assumes that disturbance-related wood removals (D) are uncorrelated to rotation length (T). This assumption is thought to be justified by reports in the literature that the susceptibility of forests to disturbances such as droughts, pests, diseases, fires and storms differ from one disturbance to another and appear to be more strongly driven by the interaction between local climatic and edaphic conditions, tree species, homogeneity of the stand structure, skewness of age distribution, root and canopy architectures, and density of the stands rather than rotation length itself (Jactel et al., 2009; Lévesque et al., 2013; Martin and Ogden, 2006; Mitchell, 2012; Pretzsch et al., 2013; Schütz et al., 2006; Seidl et al., 2011; Valinger and Fridman, 2011).

\subsection{Parameterization}

Projection of the future carbon balance of the forest sector requires that the mass balance model be parameterized with observations of the partitioning of NPP. This information was compiled from the literature (Table 1). NBP, harvest, disturbances and respiration observations for the EU (including both temperate and boreal forests) were normalized by NPP. Although most of the fluxes have been observed, our approach required decomposing $R_{h}$ into $R_{\text {hgrowth, }} R_{\text {hdebris }}$ and $R_{\text {henv }}$, also normalized by NPP as $r_{\text {root-leaves }}, r_{\text {debris }}$ and $r_{e n v}$, which have not been reported as such. In this study, $r_{\text {root-leaves }}$ was defined as the NPP-normalized 
Table 1

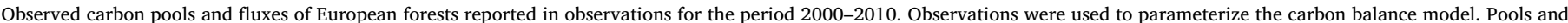

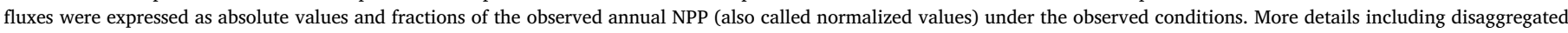
data and/or data covering more regions can be found in the respective referenced studies.

\begin{tabular}{|c|c|c|c|c|c|c|}
\hline Pool or flux & $\begin{array}{l}\text { Symbol in } \\
\text { text }\end{array}$ & $\begin{array}{l}\text { Absolute } \\
\text { value }\end{array}$ & Units & Normalized value & $\begin{array}{l}\text { Range in the } \\
\text { sensitivity analysis }\end{array}$ & Source \\
\hline C-stock in biomass and soil & $\mathrm{B}$ & 17490 & $\mathrm{~g} \mathrm{C} \mathrm{m}^{-2}$ & 32.2 & & Pan et al. (2011) \\
\hline C-stock in living biomass & $\mathrm{B}_{1}$ & 6351 & $\mathrm{~g} \mathrm{C} \mathrm{m}^{-2}$ & 19.6 & & \\
\hline Net primary production & NPP & 544 & $\mathrm{gC} \mathrm{m}^{-2} \mathrm{yr}^{-1}$ & 1.00 & & Luyssaert et al., (2007)) \\
\hline Net biome production & NBP & 89 & $\mathrm{gC} \mathrm{m}^{-2} \mathrm{yr}^{-1}$ & 0.14 & & Pan et al. (2011) \\
\hline Harvest & $\mathrm{H}$ & 70 & $\mathrm{~g} \mathrm{C} \mathrm{m}^{-2} \mathrm{yr}^{-1}$ & 0.13 & {$[0.07-0.28]$} & $\begin{array}{l}\text { Luyssaert et al. (2010), FAO (2009), Dolman et al. } \\
\text { (2012) }\end{array}$ \\
\hline Disturbance & $\mathrm{D}$ & 5 & $\mathrm{~g} \mathrm{C} \mathrm{m}^{-2} \mathrm{yr}^{-1}$ & 0.01 & & $\begin{array}{l}\text { Dolman et al. (2012), Luyssaert et al. (2007), Van der } \\
\text { Werf et al. (2009) }\end{array}$ \\
\hline Average rotation period & $? ?$ & 85 & years & - & {$[42-170]$} & $? ?=\mathrm{B}_{1} /(\mathrm{H}+\mathrm{D})$ \\
\hline Recalcitrant fraction & $\mathrm{RF}$ & & & 0.1 & & \\
\hline $\begin{array}{l}\text { Observed heterotrophic } \\
\text { respiration }\end{array}$ & $\mathrm{R}_{\mathrm{h}}$ & 387 & $\mathrm{~g} \mathrm{C} \mathrm{m}^{-2} \mathrm{yr}^{-1}$ & 0.71 & & Luyssaert et al. (2007) \\
\hline \multirow{4}{*}{$\begin{array}{l}\text { Adjusted heterotrophic } \\
\text { respiration }\end{array}$} & $\mathrm{R}_{\mathrm{h}}{ }^{\prime}$ & 383 & $\mathrm{gC} \mathrm{m}^{-2} \mathrm{yr}^{-1}$ & 0.7 & & $\mathrm{Rh}^{\prime}=\mathrm{NPP}-\mathrm{H}-\mathrm{D}-\mathrm{L}-\mathrm{NBP}$ \\
\hline & $r_{\text {root-leaves }}$ & & & 0.3 & & $\begin{array}{l}\text { (NPPleaf }+ \text { NPProot)/(NPPtotal) where the } \\
\text { estimates of the NPP components are based on } \\
\text { Luyssaert et al. (2007) }\end{array}$ \\
\hline & $r_{\text {debris }}$ & & & 0.1 & & f_litter * $(H+D) *(1-R F)$ \\
\hline & $\mathrm{r}_{\mathrm{env}}$ & & & 0.3 & {$[-0.15$ to 0.45$]$} & $\mathrm{Rh}^{\prime}-r_{\text {root-leaves }}-\mathrm{r}_{\text {debris }}$ \\
\hline
\end{tabular}

heterotrophic respiration from the decomposition of leaf and root litter and estimated as:

$r_{\text {root-leaves }}=\frac{N P P_{\text {leaf }}+N P P_{\text {root }}}{N P P_{\text {total }}}$

where the components of NPP allocated to leaf ( $\left.\mathrm{NPP}_{\text {leaf }}\right)$ and root $\left(\mathrm{NPP}_{\text {root }}\right)$ were based on a literature compilation [Luyssaert et al., 2007]. The $r_{\text {debris }}$ component is the heterotrophic respiration from woody debris left on site following harvest and/or disturbance and can be formalized as:

$r_{\text {debris }}=f_{\text {litter }} *(H+D) *(1-R F)$

where $f_{\text {litter }}$, the fraction of wood harvest left on site, was taken from Penman et al. (2003) and Lippke et al. (2011) and RF, the recalcitrant fraction of such wood residuals, from Trømborg et al. (2011) and Profft (2009). Finally, as the most uncertain component of $\mathrm{R}_{\mathrm{h}}, r_{\text {env }}$ was estimated for the period 2000-2010 such that it closes the mass balance for the observed values when $R_{h}$ is formalized as the sum of three components, $r_{\text {root-leaves }}, r_{\text {env }}$ and $r_{\text {debris: }}$ :

$r_{\text {env }}=R_{h}-r_{\text {root-leaves }}-r_{\text {debris }}$

Parameters for describing and projecting the carbon storage in wood products and carbon substitution through displacement of wood uses are presented in Table 2, along with the references. These parameters include the fraction of residue left on site after harvest and for each wood-products pool (long-lived timber, medium-lived timber, pulp and energy) its amount in terms of fraction of the total biomass export, i.e., harvested biomass minus the residue, its expected lifetime, and substitution coefficient.

This study includes an age-effect of harvest intensity by building on an ensemble of reported age-NPP relationships for a variety of temperate and boreal forest types (He et al., 2012; Wang et al., 2011). First, each age-NPP relationship was converted into an age-MAI (mean annual increment) relationship and normalized by its maximum MAI. For each rotation length (i.e., harvest level) simulated by the model, the ensemble of normalized MAI curves thus provides a statistical distribution of NPP reduction factors, $\alpha_{T}$ in Eq. (7), represented by a mean and standard deviation (Fig. S2).

Subsequently, the model was used for testing the sensitivity of the sequestration efficiency of the forest sector to the uncertainty in the key processes of carbon management. The parameter ranges applied in the sensitivity analysis are listed in Table 1 for parameters representing physical processes and in Table 2 for parameters representing substitution and displacement.

Table 2

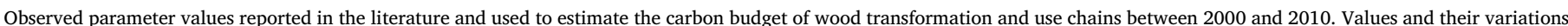
are listed as used in the carbon balance model and the sensitivity analysis.

\begin{tabular}{|c|c|c|c|c|c|c|}
\hline \multirow[t]{2}{*}{ Wood pool } & \multirow[t]{2}{*}{ Parameter } & \multirow[t]{2}{*}{ Default value } & \multicolumn{2}{|l|}{ Sensitivity } & \multirow[t]{2}{*}{ Unit } & \multirow[t]{2}{*}{ Source } \\
\hline & & & Range & Distribution & & \\
\hline Residuals & Fraction of harvested wood left on site & 0.5 & {$[0.4-0.6]$} & Uniform & - & \\
\hline \multirow[t]{3}{*}{ Long-lived timber } & Fraction of removed wood & 0.12 & & & - & Eggers (2002) \\
\hline & Expected lifetime & 50 & & & Years & \\
\hline & Substitution coefficient & 1.1 & {$[0.28-2.1]$} & Log-normal & - & Table S1 \\
\hline \multirow[t]{3}{*}{ Medium-lived timber } & Fraction of removed wood & 0.20 & & & - & Eggers (2002) \\
\hline & Expected lifetime & 16 & & & Years & \\
\hline & Substitution coefficient & 0.55 & {$[0.09-3.3]$} & Normal & - & Table S1 \\
\hline \multirow[t]{3}{*}{ Pulp } & Fraction of removed wood & 0.33 & & & - & Eggers (2002) \\
\hline & Expected lifetime & 4 & & & Years & \\
\hline & Substitution coefficient & 0 & & & - & Table S1 \\
\hline \multirow[t]{3}{*}{ Energy } & Fraction of removed wood & 0.35 & & & - & Eggers (2002) \\
\hline & Expected lifetime & 1.7 & & & Years & \\
\hline & Substitution coefficient & 0.76 & [0.46-0.94] & Log-normal & - & Table S1 \\
\hline
\end{tabular}




\subsection{Sensitivity analysis}

Five key parameters, i.e., (1) harvest intensity, (2) fraction of wood left on site as residue, (3) substitution efficiency, (4) intensity of the age-related decline in NPP and (5) the environment-related fraction of $R_{h}$ ( $r_{\text {env }}$ ) were subjected to a sensitivity analysis to reveal how their uncertainties affect the carbon balance of the forest sector. The range of the parameter values were based on a literature study so as to reflect current uncertainty $\left(\mathrm{r}_{\text {env }}, \mathrm{f}_{\text {litter }}, \mathrm{S}, \alpha_{T}\right)$ and/or credible options of management strategies ( $\mathrm{H}, \mathrm{S}$ ) (Tables 1 and 2) and propagated to the sequestration efficiency of the forest sector using Eq. (4) by means of ensemble Monte Carlo simulations consisting of 3000 simulations with randomized sampling of the five parameters. Statistical analysis of the ensemble of Monte Carlo simulations enabled us to disentangle the effects of each parameter on the sequestration efficiency. Similarly, the ensemble Monte Carlo simulations allowed us to delimit a safe operational space for forest management and subsequent wood use or in other words, identify the parameter values for forest management and wood use that would reduce the growth rate of atmospheric $\mathrm{CO}_{2}$ concentration.

\subsubsection{Harvest levels}

Today's harvest level could be reduced: thereby restoring biodiversity and thus satisfying ecological concerns (Christensen et al., 2005; Vandekerkhove et al., 2009). Halving harvest levels, for example, implies that about half of Europe's currently managed forest would have to be taken out of production. Without a parallel halving of wood consumption in Europe, such a measure would result in a considerable displacement of the forest sector's carbon emissions to other regions in the world. On the other hand, today's harvest levels could be increased to satisfy economic demands and concerns. Given that the present day harvest levels of 12 out of 34 Pan-European countries is below $50 \%$ of the annual increment, (Forest Europe et al., 2015), doubling today's harvest level could still be within or close to the biological limits considered to be sustainable from a production point of view in these regions. In this study, it was considered that European society has the choice of managing its forest anywhere along this gradient, hence, harvest levels were uniformly varied between the extensive option, where future harvest and disturbances are half of today's level and the intensive option, where future harvest and disturbances are double those of today (Table 1). Current policies are leaning towards increasing rather than decreasing harvest, which was represented in this study by applying a non-symmetrical uniform distribution around today's level.

\subsubsection{Residue left on site}

A considerable amount of forest biomass is stored belowground in components such as the roots; harvesting will therefore always leave some residue on site, i.e., at least the fine root biomass. Concern that harvesting may export valuable nutrients from the forest and limit future tree growth, has resulted in the common practice of leaving leaves, roots, branches and bark on site and only removing the stem wood (Evans et al., 2013). At present about 50\% (Lippke et al., 2011; Penman et al., 2003) of the biomass is left as residue and in extreme cases this value could increase to $60 \%$ (Eggers, 2002; Landmann and Nivet, 2014). Under more intensive practices, an estimated $40 \%$ of the biomass is left on site (Nabuurs et al., 2001). In this study, the observed range of $40-60 \%$ residue left on site was assumed to be uniformly distributed given the lack of data to justify any other type of statistical distribution (Table 2).

\subsubsection{Substitution efficiency}

Substitution coefficients have been reported for a large variety of wood uses and it was therefore possible to derive separate coefficients for each of the three categories of wood products, i.e., biofuel, mediumlived timber and long-lived timber (Table 2 and Supplementary
Materials). Despite the relative wealth of data, the definition and use of substitution coefficients is subject to large uncertainties due to their dependence on methodological choices to define the characteristics of the industries, and the reference fossil-intensive scenario used (Hellweg and i Canals, 2014). At present the range of observed substitution coefficients is so large that it contains efficiencies for which wood use is a net benefit to the atmosphere or a net loss of carbon compared to alternative solutions. Given this large uncertainty, substitution was reported to have a large impact on the wood-products carbon balance (Fortin et al., 2012; Lundmark et al., 2014).

Based on the distribution of the compiled literature values, lognormal, normal and uniform probability density functions were fitted to the energy, medium-lived and long-lived timber uses respectively. Individual substitution coefficients reported in the literature represent specific products constructed by making use of specific processes and technologies, and compared to specific reference scenarios for a given alternative product or energy source. Therefore, it seems unlikely that the most/least efficient substitution that relates to use of one specific wood product, would become the overall substitution efficiency for all wood uses in Europe, because this would imply that the total European harvest had been used to produce this single product. For this reason, the uncertainty range assigned to the substitution coefficients was taken from the calculated range, restricting values to no more than two standard deviations away from the mean.

From a socioeconomic point of view, the three wood-product pools can be regarded as interdependent. Hence, it seems reasonable to expect that societies with high substitution efficiencies for one pool are more likely to have high substitution efficiencies for the other woodproduct pools. This reasoning is partly justified by the definition of the substitution coefficients: indeed, substitution potential is driven by the extent to which the current technology depends on fossil energy and on the efficiency of the wood transformation chain. The inter-dependency of the substitution coefficient between wood-use pools was implemented in the Monte Carlo approach by first sampling the observed distributions of the substitution coefficients, then sorting the sampled values and finally randomly selecting substitution efficiency for one wood use and using the efficiency coefficients with the same rank for the other wood uses.

Substitution efficiencies are in principle estimated for the marginal production between a fossil-based and wood-based scenarios (Smyth et al., 2014; Werner et al., 2006). This study followed this definition and substitution coefficients were, therefore, applied to the marginal production, in other words, the production of wood products relative to the wood products in the reference simulation where all parameters were set to current values. As such, substitution accounted for the increase or decrease in wood-product production resulting from both changes in harvest level and in sink strength. As a consequence, an increase in wood production compared to the reference simulation will reduce the total $\mathrm{CO}_{2}$ emissions through substitution or avoidance of emissions within or outside the forest sector. Conversely, a decrease in wood-product production compared to the reference simulation will give rise to additional carbon emissions due to the need for more fossilfuel intensive alternatives to provide products and energy currently provided by wood.

\subsubsection{Sink strength}

The causes of today's carbon sink are still under debate (see Introduction for details)), making it difficult to predict its future behaviour within a meaningful confidence interval (Friedlingstein et al., 2014). Projections of the evolution of the European carbon sink as a response to environmental changes -under constant management practice between now and 2100-cover the whole range from maintaining the current sink for several more decades (Nabuurs et al., 2003), to sink saturation (Nabuurs et al., 2013), which could progressively become neutral or change sign to become a source, if extreme events such as the 2003 European drought were to become more frequent 
(Ciais et al., 2005; Lindner et al., 2014). Simulated trends in the NBP to NPP ratio were obtained from the CMIP5 model intercomparison exercise and. When projected onto the observed value, the sink strength by the end of the 21st century may vary by -0.3 to 1.3 times its current strength (Fig. S3). In this study, sink strength evolutions were varied between -0.5 and 1.5 times the current sink strength in 2100 by adjusting the environmentally driven soil heterotrophic respiration component, $r_{\text {env }}$. Varying the value of this parameter in the sensitivity analysis represents present-day uncertainty of the effects of the environmental conditions, e.g., $\mathrm{CO}_{2}$ atmospheric concentration, nitrogen fertilization, and temperature change, on the functioning of forest ecosystems. The model parameter $r_{\text {env }}$ was adjusted to make the model simulate an NBP that matched the prescribed sink strength. Hence, the simulations spanned eventualities of an enhanced sink, neutral sink behaviour and the conversion from today's sink to a source. All simulations in the ensemble started from the same sink strength and varied linearly to their value for the year 2100 .

\subsubsection{Age-related decline of NPP}

Although an age-related decline of NPP has been widely observed, the underlying mechanisms are still being debated (Ryan et al., 1997; Tang et al., 2014). The variation found in literature compilations of ageNPP relationships for boreal and temperate forests (He et al., 2012; Wang et al., 2011) was used as a proxy of the uncertainty of the timing and strength of the age-related decline of NPP. For each rotation length (i.e., harvest level) simulated by the model, the compilation of age-NPP relationships thus provided a mean and standard deviation of NPP reductions factors $\left(\alpha_{T}\right)$. We assumed a normal distribution, mean and standard deviation could be used to derive a statistical distribution of NPP reductions factors (Fig. S2), which could then be sampled as part of the sensitivity analysis while constrained to remain within two standard deviations of the distribution.

For example, an extensive harvest scenario involving a halving of the reference harvest rate corresponds to a doubling of the rotation length, which according to the composite growth relationships gives a reduction of the average NPP by a factor normally distributed around 0.88 with standard deviation \pm 0.1 and constrained between 0.65 and 1.

\subsubsection{Analysis of variance (ANOVA)}

Analysis of variance (ANOVA Type-I) of the sequestration efficiency for a given time horizon (i.e., 25, 50, 75, 100, 125 and 150 years) was used to disentangle the uncertainty attributable to one of the five parameters included in the sensitivity analysis: namely, harvest level, residuals left on site, substitution efficiency, age-effect and sink strength. The total variance can then be decomposed as the sum of the variance explained by the effect of the five key parameters and their interactions. The Type-I ANOVA was repeated successively changing the order of the terms so that each parameter was tried at first and last position in the regression equation on which ANOVA is based. No change in the order of magnitude or in the ranking of the contributions was found. Only interaction terms of first degree (two parameter interactions) were taken into account. The variance (sum of squares) calculated for each factor is divided by the total variance (total sum of squares) yielding the fraction of the total variance explained by a given factor (Von Storch and Zwiers, 2001).

\section{Results}

The dominant drivers of the carbon sequestration efficiency of forests vary with time (Fig. 1). For time horizons of 25 years, $29 \%$ of the variation in carbon sequestration efficiency depends on the amount of harvest residue left on site and $24 \%$ on the harvest levels, substitution potential and their interaction. The assumed shape of the age-NPP relationship and the sink strength explain respectively $23 \%$ and $14 \%$ of the sequestration efficiency. The three management and wood-use parameters with their interactions thus together explain 53\% of the simulation variances. The physiological components of the carbon balance (age-effect or the effect on NPP of varying the rotation length, and sink strength or the response of forest to environmental and climate change) contribute another $37 \%$ to the variation of the sequestration efficiency displaying a balance in driving factors between forest ecosystem and wood-use sector factors.

The dependency of the carbon sequestration efficiency on the parameters describing wood removal and use through harvesting, substitution and residue management decreases with time (Fig. 1) such that after 50 years, the sink strength is with $38 \%$, already the single largest contributor to the total variance. For time horizons exceeding 75 years, more than half $(57 \%)$ of the variation in sequestration efficiency is explained by the strength of the sink. Since all scenarios start from the same initial value of the sink and then linearly reach their target value over 100 years, the increase in the contribution of the sink strength to the total variance contribution is correlated $\left(R^{2}=0.98\right)$ to the increase in the total variance with time.

Sequestration efficiency was found to be driven primarily by the sink strength $\left(R^{2}=0.8\right.$ at 100 years) with larger sink values resulting in larger forestry carbon sequestration (shown for a 100-year time horizon in Fig. 2a). Despite the dominance of the evolution of the sink on the sequestration efficiency at this time horizon, human interference in the forest sector still has a role to play (Fig. 2b-e). For a given evolution of the sink, leaving more or less residue on site will respectively decrease or increase the sequestration efficiency by 0.03 on average with little variation from one sink strength to another (standard deviation 0.004 across sink strengths). These variations in sequestration efficiency are a response to a shift in carbon allocation, from left to decompose through respiratory fluxes under extensive residue management to allocated to substitution-generating wood products under intensive residue management (Fig. 2c). Given the present-day net primary production of $544 \mathrm{~g} \mathrm{C} \mathrm{m}^{-2} \mathrm{yr}^{-1}$ and harvest intensity of $2.6 \mathrm{~m}^{3} \mathrm{ha}^{-1} \mathrm{yr}^{-1}$ (Table 1), this change in sequestration efficiency represents a carbon sequestration of $16 \mathrm{~g} \mathrm{C} \mathrm{m}^{-2} \mathrm{yr}^{-1}$ or $61 \mathrm{~kg} \mathrm{C}$ per harvested $\mathrm{m}^{3}$.

Similarly, aiming for wood usage with high or low substitution efficiency will respectively increase or decrease the sequestration efficiency of the forest sector by 0.01 on average (standard deviation 0.003 across sink strengths) (Fig. 2d), a small effect of substitution alone consistent with the variance decomposition analysis showing that substitution is only a major driver of sequestration efficiency in its interaction with harvest (Fig. 1).

Harvest levels, however, display a somewhat different relation to sequestration efficiency. The effect of management strategy on sequestration efficiency will depend on the sink evolution, which owing to a lack of process understanding cannot be intentionally managed yet (Fig. 2b). Under an increased sink scenario, sequestration efficiency of the forest sector will be 0.15 with current harvest levels. Doubling the harvest volume will reduce the sequestration efficiency by 0.05 (equivalent to a loss of sequestration of $27 \mathrm{~g} \mathrm{C} \mathrm{m}^{-2} \mathrm{yr}^{-1}$ at European scale), whereas halving the harvest volume will increase it by 0.02 (equivalent to a gain in sequestration of $11 \mathrm{~g} \mathrm{C} \mathrm{m}^{-2} \mathrm{yr}^{-1}$ at European scale) showing the benefit of reducing the harvest under this scenario. The benefits of reducing the harvest volume would, however, be lost if over the course of the twenty-first century forests were to revert to carbon sources. Sequestration efficiency would then be $0.04,0.04$ and 0.02 , for decreased, current and increased harvest levels alike. If climate change leads to a stronger biospheric sink, forest management could enhance the carbon sequestration efficiency by reducing harvest levels. If however, forests responded to climate change by increasing their carbon respiration, forest management would lose its potential to increase the sequestration efficiency of the forest sector.

The safe operational space is defined by the parameter combinations that result in an increase in the sequestration efficiency compared to current practices. In Fig. 2 the safe operational space for the time 


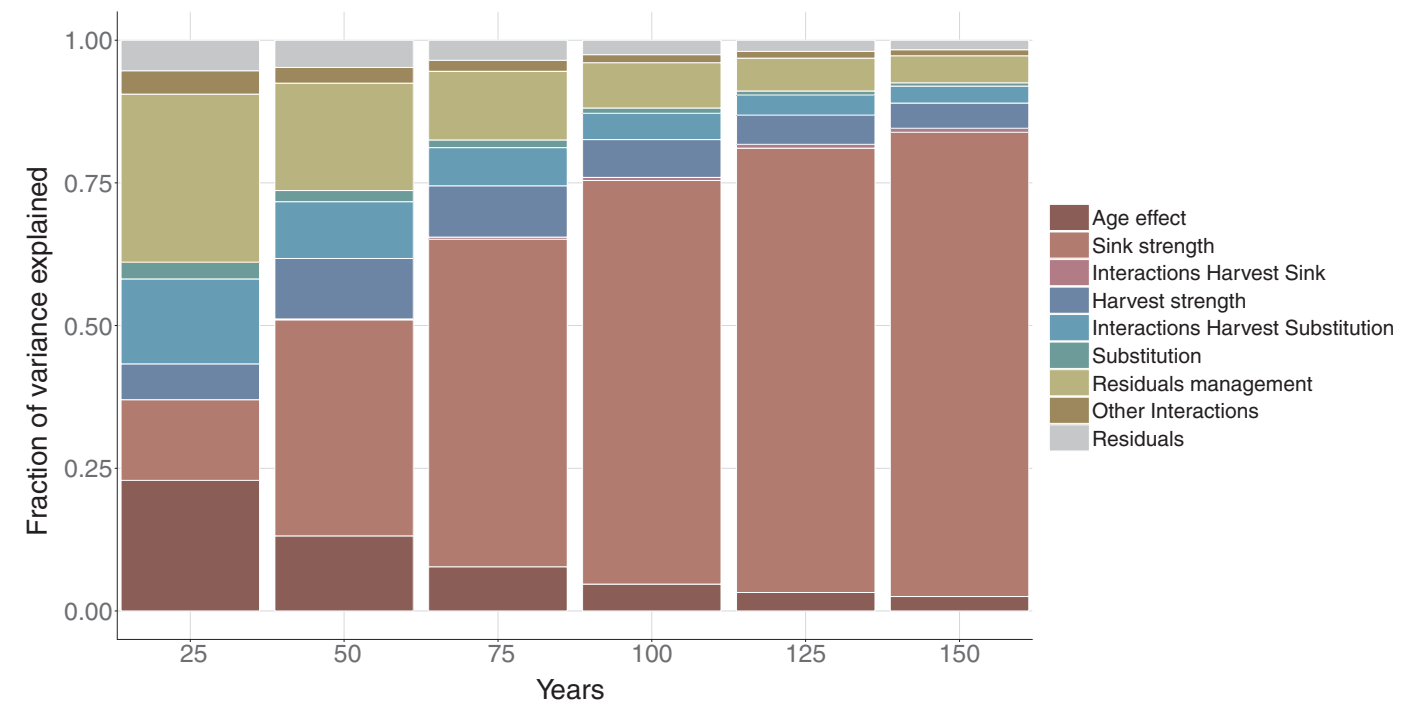

Fig. 1. Decomposition of the total variance of the sequestered carbon into its determinants for time horizons between 25 and 150 years.

horizon of 100 years is delineated with a dashed line and simulations falling within the safe space are identified with hatching and dashed whiskers in Fig. 2. At 100 years, $69 \%$ of the strong sink simulations (13\% of the simulations when all time horizons were combined Fig. 3) fall within the safe space. This number drops to $63 \%$ for the current sink strength, $24 \%$ with a weakened sink and less than $1 \%$ when the carbon sink in forests becomes neutral. If the forest sink were to reverse to neutral or become a source, the forest sector as a whole would still remove atmospheric $\mathrm{CO}_{2}$ and thus act as a net carbon absorber but there is no combination of management practices and wood use that would allow the sector to maintain or increase its current sequestration efficiency.

Threshold values resulting in a safe space under a given sink evolution and for a given time horizon are listed in Table 3 for substitution efficiency, residue management and harvest levels. If the sink reverses into a source by the year 2100 , no parameter combination will result in a carbon balance equal or better than today's sequestration efficiency (Fig. 3 and Table 3).

\section{Discussion}

\subsection{A safe operational space}

Our results show that when testing for realistic future wood uses and harvest practices, the forest sector as a whole will in $98 \%$ of the simulations over all time horizons remove atmospheric $\mathrm{CO}_{2}$ and thus act as a carbon absorber, even if the forests themselves become a carbon source as a response to environmental changes (Fig. 2).

If however, the aim is not to simply keep sequestering carbon but is to sequester more carbon than at present, a rather limited operational space was found for future wood-use and harvest practices (Fig. 3 and Table 3). The key determinant of this safe operational space is the interaction between the planning horizon and the future evolution of the forest sink. Under the current growing conditions, the safe operational space depends on the ability of the forest sector to realize an efficient and effective substitution of wood for more fossil fuel-intensive materials. Our results (Fig. 2) show, however, that for planning horizons exceeding 50 years, the capacity of the forest sector increasingly depends on the response of the forest to climate and environmental changes rather than on forest management (Hirsch et al., 2001) and technical advances in wood use (Ragauskas et al., 2006).

Within a single sink strength scenario, the large overlap between different management strategies (Fig. 2b-d) demonstrates that, except for the extreme cases, a similar sequestration efficiency can be realized through different combinations of residue management, harvest intensity and substitution efficiencies. By changing the specifics of wood use and substitution (Fig. 2b), the sequestration efficiency of the forest sector can be altered by more than $100 \%$ for a given harvest level and sink strength. This would be the case when switching from harvest practices that leave $60 \%$ of the harvest as residue and use the harvested biomass to substitute for a low-emitting energy alternative such as nuclear electricity (low substitution potential) to harvest practices that leave $40 \%$ residues and use the wood to substitute concrete in longlived buildings (high substitution potential).

If in 50 years from now, forest turns into a weaker (reduced by up to $60 \%$ in 2060), similar or stronger sink than today, there is a safe operational space where the present sequestration efficiency of the forest sector can be sustained or even improved. If the current sink weakens, then an increase in carbon sequestration efficiency at a 100-year horizon is only possible for substitution efficiencies exceeding 0.72 for long-lived wood products and 0.45 for energy substitution, irrespective of the harvest level and residual management. Such substitution efficiencies could be realized, for example, in Austria by replacing construction materials such as concrete, steel and aluminium by sawnwood (Bird, 2013) or in France by displacing oil-based heating by wood pellets (Fortin et al., 2012).

If in 50 years from now the forest sink becomes neutral or a carbon source, and wood transformation and use technology has not considerably advanced, a decrease in sequestration efficiency is to be expected compared to today. If the sink were to become neutral, then substitution efficiencies of at least 1.68 for long-lived timber and 1.02 for energy are required for the forest sector to enhance its current sequestration efficiency over a 100-year time horizon. Such efficiencies could be realized through the substitution of steel joists by wooden beams in the construction industry (Bergman et al., 2014) or substitution of fossil fuel fired electricity by wood-based electricity in the energy industry (Cannell, 2003; Lippke et al., 2011).

Harvesting more wood may increase the sequestration efficiency if environmental changes start reversing the carbon sink (Fig. 2b), but it is not sufficient: channelling this additional wood to uses where the substitution effect is highest is crucial if Europe is to maintain the sequestration efficiency at or above today's level. If the forests have turned into carbon sources, sequestration efficiencies could still be increased for time horizons of 25, 50 or 75 years. Substitution efficiencies will then need to exceed 1.63 for long-lived products, and 1.00 for energy production. In addition, less than $46 \%$ of the harvest should be left on site and the current harvest level will have to be increased by 45\% (Table 3). 

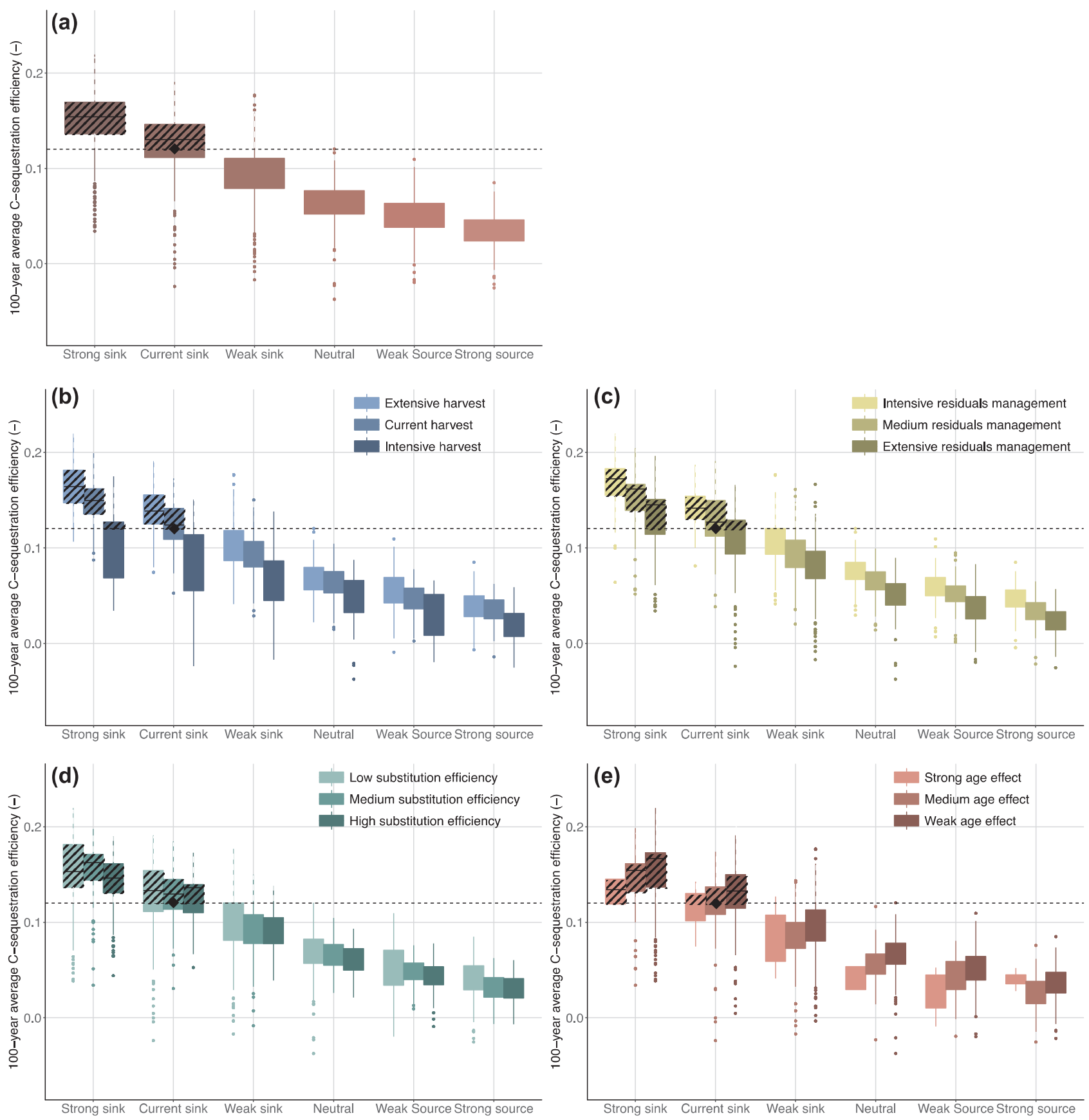

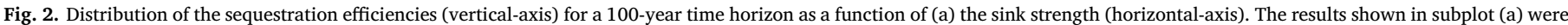

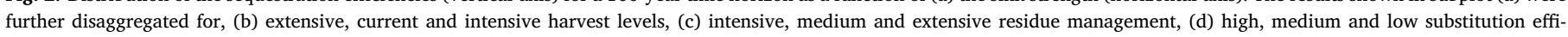

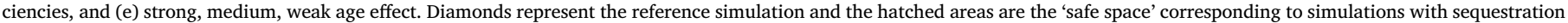
efficiency above the reference simulation.

Despite the current uncertainty in how the sink strength of forest will evolve in the future, financial incentives already exist for stimulating biomass energy production. The carbon neutrality argument for biomass energy has been used to justify the development of the wood sector (Johnson, 2009), to support the construction of biomass-burning energy plants (Beaton et al., 2011) or subsidize households to switch from fossil-based to wood-based energy systems (Cansino et al., 2011). Our results and others (Fortin et al., 2012; Holtsmark, 2012; Hudiburg et al., 2011; Kaipainen et al., 2004; Sievänen et al., 2014) show that such initiatives are at best only partly backed by scientific evidence.

Irrespective of the future evolution of the sink strength, our results caution against putting too much weight on forest management for planning horizons of 50 years or more. Even if the current sink strength is maintained in Europe, completely different forest management strategies such as halving or doubling harvest levels only affect the sequestration efficiency, which accounts for the forest sink, products pool and substitution, by +9 to $-20 \%$ on average $\left(+11 \mathrm{~g} \mathrm{C} \mathrm{m}^{-2} \mathrm{yr}^{-1}\right.$ to $-23 \mathrm{~g} \mathrm{C} \mathrm{m}^{-2} \mathrm{yr}^{-1}$ ). For scenarios with a decreasing carbon sink, the impact of the management strategy on the sequestration efficiency is even lower (Fig. 2). Although the sink scenarios applied in this study imply a $25 \%$ chance that the current sink reverts to a source, $98 \%$ of the simulations predict that the forest sector as a whole will remain a net carbon absorber thanks to substitution and carbon storage in wood products. The possibilities for further increasing the carbon sequestration efficiency of the forest sector appears, however, to be rather limited with only $13 \%$ of the simulations leading to an increased 


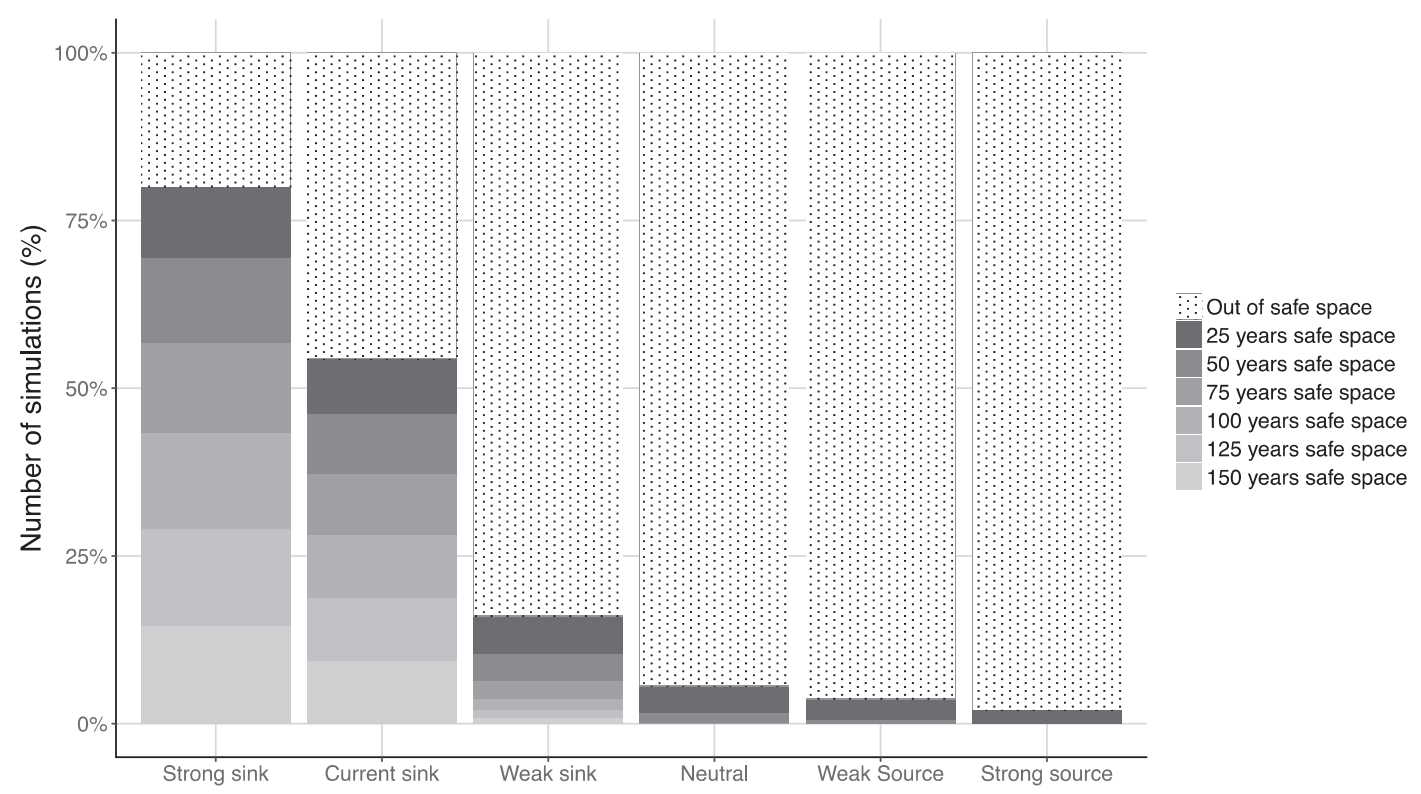

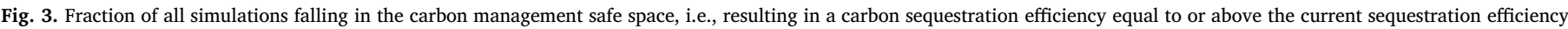
calculated with best-guess parameters for time horizons between 25 and 150 years.

sequestration efficiency in 100 years. Increased sequestration efficiencies can only be reached if the sink is maintained or increased and if the wood is used in applications that come with a substitution potential well above unity.

\subsection{Setting the level of ambition}

In the previous paragraphs, the safe space was defined by using present-day sequestration efficiency as the baseline efficiency. A similar analysis could have been carried out defining the safe space from a dynamic baseline as the projected sequestration efficiency that would result from forests response to climate change without any change in management and wood-use practices. Our choice for this setting reflects the ambition of the forest sector towards mitigating fossil fuel emissions by sequestering carbon. In a context of still increasing emission from burning fossil fuel, the strict setting by choosing present-day sequestration efficiency as the baseline is consistent with the attempt to avoid a future in which the forest sector sequesters less carbon than today, requiring other sectors to reduce their emissions even more.

The wording in the Paris agreement (UNFCCC, 2015), Article 5 "Parties should take action to enhance the sink", leaves room for different interpretations because it is not stated which baseline should be used. Any reference could be used, including the sink under future climate assuming current management practices will continue in the future. Which is the baseline used in some countries' intended nationally determined contributions. Using such a baseline means that if the future sink turns out to be a source, forest management that decreases the source compared to the source under BAU would satisfy Article 5. Given that the forest sector would then act as a source, it would have become part of the problem rather than contributing to the solutio$\mathrm{n}$-yet still in line with international agreement on climate change mitigation.

Whether today's sequestration efficiency or any other reference is used as the baseline thus reflects the ambition of the forest sector. Using today's sequestration efficiencies would show a sound commitment of the sector to reducing the increase of atmospheric $\mathrm{CO}_{2}$ concentration. Using other baselines, especially dynamic baselines, could lead to the forest sector being accused of 'greenwashing', i.e., of complying with the letters of the Paris Agreement but not its spirit.

\subsection{Compensating for losses in sequestration efficiency}

If current sequestration efficiencies cannot be sustained, the absolute amount of carbon sequestrated in the forest sector could be maintained by compensating the loss of efficiency by an increase of the NPP of European forests (see Eq. (2)). Total NPP could be increased by expanding the forest area, managing the age distribution towards younger forests, and/or using agricultural practices such as irrigation and/or fertilization. Fertilization and irrigation, however, have also been reported to act on sequestration efficiency: fertilization may increase the sequestration efficiency by reducing heterotrophic respiration (Janssens et al., 2010), while irrigation, on the other hand, may decrease sequestration efficiency by increasing soil respiration (Hartmann et al., 2016). Afforestation, managing the age structure, fertilization and irrigation may also have adverse direct and indirect effects on biodiversity (Burrascano et al., 2016), surface and groundwater quality and quantity (Jackson et al., 2005; Vörösmarty et al., 2013), and other greenhouse gas emissions (Aber, 1992). If the European forest sector should fail to sustain or enhance its current level of carbon sequestration, reducing the growth rate of atmospheric $\mathrm{CO}_{2}$ concentration will require other sectors to compensate with additional emission reductions or alternatively rely on negative emission technologies that are, however, not operational yet (Smith et al., 2016).

\subsection{Reconciling carbon management studies}

Previously, the conditions for carbon-optimal forest management strategies were studied under a variety of assumptions about the evolution of the forest sink. Some authors implicitly assumed that the current sink in mature forests would be sustained over the time-horizon of their studies (Fortin et al., 2012; Hudiburg et al., 2011; Liu and Han, 2009; Perez-Garcia et al., 2007; Trømborg et al., 2011). Other studies implicitly followed Odum's framework (Odum, 1969) by assuming mature forests are carbon neutral (Lippke et al., 2011). Yet others based their analysis on explicit variations in the sink whether as a response to age structure changes or with an increasing productivity as a result of temperature and environmental changes (Poudel et al., 2012; Zubizarreta-Gerendiain et al., 2016). Given that the future sink strength is a key driver of the sequestration efficiency of the forest sector, it is not surprising that studies covering the whole range of scenarios came to apparently conflicting conclusions. Fig. 2 shows how apparently 
Table 3

Safe space thresholds for substitution, residue management and harvest intensity. If the forest sector operates at parameter values below (residue left on site and harvest) or above (substitution efficiency) these thresholds, current sequestration efficiency can be maintained or increased for the given time-horizon. A minus $(-)$ indicates that no parameter value permits a maintenance of the current sequestration efficiency, a plus (+) indicates that all parameter values are consistent with the maintenance of the current sequestration efficiency.

Mimimum substitution efficiency for long-lived timber allowing a safe space

\begin{tabular}{lllllll}
\hline Time (years) & 25 & 50 & 75 & 100 & 125 & 150 \\
\hline Strong_sink & + & + & + & + & + & + \\
Current_sink & + & + & + & + & + & + \\
Weak_sink & 0.17 & 0.17 & 0.17 & 0.17 & 0.22 & 0.22 \\
Neutral & + & 0.33 & 0.36 & 0.55 & - & - \\
Weak_source & 0.23 & 0.23 & 0.23 & - & - & - \\
Strong_source & + & + & - & - & - & -
\end{tabular}

Mimimum substitution efficiency for medium-lived timber allowing a safe space

\begin{tabular}{lllllll}
\hline Time (years) & 25 & 50 & 75 & 100 & 125 & 150 \\
\hline Strong_sink & + & + & + & + & + & + \\
Current_sink & + & + & + & + & + & + \\
Weak_sink & -1.13 & -1.13 & -1.13 & -1.13 & -0.95 & -0.95 \\
Neutral & + & -0.54 & -0.35 & 0.16 & - & - \\
Weak_source & -0.87 & -0.87 & -0.87 & - & - & - \\
Strong_source & + & + & - & - & - & -
\end{tabular}

Mimimum substitution efficiency for energy allowing a safe space

\begin{tabular}{lcccccc}
\hline Time (years) & 25 & 50 & 75 & 100 & 125 & 150 \\
\hline Strong_sink & + & + & + & + & + & + \\
Current_sink & + & + & + & + & + & + \\
Weak_sink & + & + & + & + & + & + \\
Neutral & + & 0.29 & 0.30 & 0.36 & - & - \\
Weak_source & + & + & + & - & - & - \\
Strong_source & + & + & - & - & - & -
\end{tabular}

Maximum residue left on site to have a safe space ( 0.6 means that $60 \%$ of the harvest is left on site as litter)

\begin{tabular}{lllllll}
\hline Time (years) & 25 & 50 & 75 & 100 & 125 & 150 \\
\hline Strong_sink & 0.59 & + & + & + & + & + \\
Current_sink & 0.59 & 0.59 & 0.59 & + & + & + \\
Weak_sink & + & + & + & 0.59 & 0.59 & 0.59 \\
Neutral & + & 0.53 & 0.47 & 0.43 & - & - \\
Weak_source & + & 0.56 & 0.43 & - & - & - \\
Strong_source & 0.55 & 0.46 & - & - & - & -
\end{tabular}

Maximum harvest intensity change ( 0.5 means a reduction by 2 of the average rotation length)

\begin{tabular}{lllllll}
\hline Time (years) & 25 & 50 & 75 & 100 & 125 & 150 \\
\hline Strong_sink & 0.55 & 0.55 & 0.55 & 0.55 & 0.55 & 0.55 \\
Current_sink & 0.54 & 0.55 & 0.55 & 0.55 & 0.55 & 0.55 \\
Weak_sink & + & + & 0.58 & 0.58 & 0.58 & 0.58 \\
Neutral & 0.53 & 0.84 & 1.64 & 1.99 & - & - \\
Weak_source & 0.52 & 1.43 & 1.47 & - & - & - \\
Strong_source & + & 1.61 & - & - & - & -
\end{tabular}

conflicting results can be sourced to differences in the assumptions, rather than differences in the process understanding.

Although our approach can reconcile apparently conflicting results by varying key assumptions, a comprehensive reconciliation would require more detailed information on the assumptions made by other studies. The current lack of such information calls for future studies on the carbon balance of the forest sector to explicitly report their assumptions in terms of: (1) evolution of the sink, (2) harvest practices, and (3) fully documented substitution potential.

Although our analysis treated Europe as a uniform entity, the different scenarios allow us to account for regional differences. All wooduse parameters being equal and harvest levels being comparable, harvest levels could be increased in regions where the sink is weak to support a well-designed chain of wood uses. When making such decisions, one needs to consider the long-term legacy of management strategies on the forest structure and by extension the forest sector. Maximizing the sequestration efficiency over a 25-50 year period calls for reducing harvest levels, which will result in higher standing biomasses. Although higher standing biomasses would increase the $\mathrm{CO}_{2}$ emissions from stand-replacing disturbances and decrease the net primary production (Lundmark et al., 2014; Luyssaert et al., 2008) it would maintain the full range of future management options.

\subsection{Limitations of the study}

Our approach has the advantage that it is informed by recent observation-based assessments (Luyssaert et al., 2010; Pan et al., 2011), addresses the complete carbon cycle of the forest sector, accounts for the major uncertainties, and separates net primary production from sequestration efficiency (see Eq (2)). Nevertheless, it comes with its own assumptions and limitations:

- The model developed for this study was one dimension by design. Spatially explicit analyses are out of reach for such an approach. The study itself focuses on the sensitivity of sequestration efficiency, the results of the study are therefore limited to sequestration efficiency and do not necessarily apply to the total carbon sink.

- The time-dependent partitioning of the variance depends on the ranges of parameter values considered in this analysis. As a precaution, care was taken to represent the current uncertainty of each factor across the timeframe of our analysis when defining the parameter ranges.

- Except for the sink strength, all other parameters are kept constant over time within a single simulation, which is thought to be acceptable for residue management and harvest practices. However, the use of a constant substitution efficiency could be questioned for two opposing reasons: the substitution efficiency is expected to increase with the advancement of technology and better resource (re) use; but at the same time, the substitution efficiency is expected to decrease over time due to a decrease in GHG emissions of the reference product and energy mix used as a reference in the life cycle analysis.

- Harvest levels, residue management, and substitution efficiencies are partly driven by the same economic, industrial and political processes and are therefore expected to be correlated with each other. Neither the present nor the future relationships between harvest levels, residue management, and substitution efficiencies could be determined and were therefore not accounted for in the simulations.

- The quantitative approach does not account for losses or gains in site fertility as could be expected from long-term changes in residue management. The observed benefits in carbon sequestration resulting from increased residue removal therefore only reflect the increase in wood available for products and carbon substitution but ignores the long-term feedback effect on the sink.

Despite the aforementioned limitations on the parameter ranges, relationships between parameters and temporal dynamics of site-fertility, the dominance of the future sink strength is believed to be a robust feature because it correctly reflects the large uncertainty of the sink strength compared to the uncertainty of the other drivers of the sequestration efficiency of the forest sector.

\section{Acknowledgements}

This work has in part been funded through the French Environment and Energy Management Agency (ADEME, Bilan Carbone de la Forêt Française programme), the European Research Council (starting grant 
242564, DOFOCO, Do Forests Cool the Earth?) and the Amsterdam Academic Alliance (AAA).

Appendix A. Supplementary material

\section{References}

Aber, J.D., 1992. Nitrogen cycling and nitrogen saturation in temperate forest ecosystems. Trends Ecol. Evol. 7, 220-224.

Anderegg, W.R.L., Kane, J.M., Anderegg, L.D.L., 2013. Consequences of widespread tree mortality triggered by drought and temperature stress. Nature Clim. Change 3, 30-36. http://dx.doi.org/10.1038/nclimate1635.

Beaton, C., Moerenhout, T., et al., 2011. Assessing the Cost-effectiveness of Renewable Energy Deployment Subsidies: Biomass in the United Kingdom and Germany. NCCR Trade Working Paper.

Beck, P.S., Juday, G.P., Alix, C., Barber, V.A., Winslow, S.E., Sousa, E.E., Heiser, P., Herriges, J.D., Goetz, S.J., 2011. Changes in forest productivity across Alaska consistent with biome shift. Ecol. Lett. 14, 373-379.

Bellassen, V., le Maire, G., Guin, O., Dhôte, J.F., Ciais, P., Viovy, N., 2011. Modelling forest management within a global vegetation model-Part 2: Model validation from a tree to a continental scale. Ecol. Model. 222, 57-75. http://dx.doi.org/10.1016/j. ecolmodel.2010.08.038.

Bellassen, V., Luyssaert, S., 2014. Carbon sequestration: managing forests in uncertain times. Nature 506, 153-155. http://dx.doi.org/10.1038/506153a.

Bergman, R., Puettmann, M., Taylor, A., Skog, K.E., 2014. The carbon impacts of wood products. For. Products J. 64, 220-231.

Bird, D.N., 2013. Estimating the Displacement of Energy and Materials by Woody Biomass in Austria. Joanneum Research Resources.

Bowden, R.D., Nadelhoffer, K.J., Boone, R.D., Melillo, J.M., Garrison, J.B., 1993. Contributions of aboveground litter, belowground litter, and root respiration to total soil respiration in a temperate mixed hardwood forest. Can. J. For. Res. 23, 1402-1407.

Bugmann, H., Bigler, C., 2011. Will the CO2 fertilization effect in forests be offset by reduced tree longevity? Oecologia 165, 533-544.

Burrascano, S., Chytrỳ, M., Kuemmerle, T., Giarrizzo, E., Luyssaert, S., Sabatini, F.M., Blasi, C., 2016. Current European policies are unlikely to jointly foster carbon sequestration and protect biodiversity. Biol. Cons. 201, 370-376.

Cannell, M.G., 2003. Carbon sequestration and biomass energy offset: theoretical, potential and achievable capacities globally, in Europe and the UK. Biomass Bioenergy 24, 97-116.

Cansino, J.M., Pablo-Romero, M. del P., Román, R., Yñiguez, R., 2011. Promoting renewable energy sources for heating and cooling in EU-27 countries. Energy Policy 39, 3803-3812.

Chapin, F.S., Matson, P.A., Vitousek, P., 2011. Principles of Terrestrial Ecosystem Ecology. Springer Science \& Business Media.

Chapin, F.S., Woodwell, G.M., Randerson, J.T., Rastetter, E.B., Lovett, G.M., Baldocchi, D.D., Clark, D.A., Harmon, M.E., Schimel, D.S., Valentini, R., et al., 2006. Reconciling carbon-cycle concepts, terminology, and methods. Ecosystems 9, 1041-1050.

Christensen, M., Hahn, K., Mountford, E.P., Odor, P., Standovár, T., Rozenbergar, D., Diaci, J., Wijdeven, S., Meyer, P., Winter, S., et al., 2005. Dead wood in European beech (Fagus sylvatica) forest reserves. For. Ecol. Manage. 210, 267-282.

Ciais, P., Reichstein, M., Viovy, N., Granier, A., Ogée, J., Allard, V., Aubinet, M., Buchmann, N., Bernhofer, C., Carrara, A., et al., 2005. Europe-wide reduction in primary productivity caused by the heat and drought in 2003. Nature 437, 529-533.

Cox, P.M., Betts, R.A., Jones, C.D., Spall, S.A., Totterdell, I.J., 2000. Acceleration of global warming due to carbon-cycle feedbacks in a coupled climate model. Nature 408, 184-187.

Cramer, W., Bondeau, A., Woodward, F.I., Prentice, I.C., Betts, R.A., Brovkin, V., Cox, P.M., Fisher, V., Foley, J.A., Friend, A.D., et al., 2001. Global response of terrestrial ecosystem structure and function to $\mathrm{CO}_{2}$ and climate change: results from six dynamic global vegetation models. Glob. Change Biol. 7, 357-373.

de Boer, H.J., Lammertsma, E.I., Wagner-Cremer, F., Dilcher, D.L., Wassen, M.J., Dekker, S.C., 2011. Climate forcing due to optimization of maximal leaf conductance in subtropical vegetation under rising $\mathrm{CO}_{2}$. Proc. Nat. Acad. Sci. USA 108, 4041-4046.

De Deyn, G.B., Cornelissen, J.H., Bardgett, R.D., 2008. Plant functional traits and soil carbon sequestration in contrasting biomes. Ecol. Lett. 11, 516-531.

Dolman, A.J., Shvidenko, A., Schepaschenko, D., Ciais, P., Tchebakova, N., Chen, T., Van Der Molen, M.K., Belelli Marchesini, L., Maximov, T.C., Maksyutov, S., et al., 2012. An estimate of the terrestrial carbon budget of Russia using inventory-based, eddy covariance and inversion methods. Biogeosciences 9, 5323-5340.

Eggers, T., 2002. The Impacts of Manufacturing and Utilisation of Wood Products on the European Carbon Budget - Internal Report 9. European Forest Institute.

Evans, A.M., Perschel, R.T., Kittler, B.A., 2013. Overview of forest biomass harvesting guidelines. J. Sustain. For. 32, 89-107.

FAO, 2010. Global Forest Resources Assessment 2010: Main Report. Food \& Agriculture Organization of the United Nations.

Forest Europe, FAO, EFI, 2015. State of Europe's Forests 2015. Ministerial Conference on the Protection of Forests in Europe.

Fortin, M., Ningre, F., Robert, N., Mothe, F., 2012. Quantifying the impact of forest management on the carbon balance of the forest-wood product chain: a case study applied to even-aged oak stands in France. For. Ecol. Manage. 279, 176-188. http:// dx.doi.org/10.1016/j.foreco.2012.05.031.

Friedlingstein, P., Meinshausen, M., Arora, V.K., Jones, C.D., Anav, A., Liddicoat, S.K. Knutti, R., 2014. Uncertainties in CMIP5 climate projections due to carbon cycle feedbacks. J. Clim. 27, 511-526.

Hartmann, M., Brunner, I., Hagedorn, F., Bardgett, R.D., Stierli, B., Herzog, C., Chen, X., Zingg, A., Graf-Pannatier, E., Rigling, A., et al., 2016. A decade of irrigation transforms the soil microbiome of a semi-arid pine forest. Mol. Ecol.

He, L., Chen, J.M., Pan, Y., Birdsey, R., Kattge, J., 2012. Relationships between net primary productivity and forest stand age in US forests. Global Biogeochem. Cycles 26.

Hellweg, S., i Canals, L.M., 2014. Emerging approaches, challenges and opportunities in life cycle assessment. Science 344, 1109-1113.

Hirsch, K., Kafka, V., Tymstra, C., McAlpine, R., Hawkes, B., Stegehuis, H., Quintilio, S., Gauthier, S., Peck, K., 2001. Fire-smart forest management: a pragmatic approach to sustainable forest management in fire-dominated ecosystems. For. Chron. 77, 357-363.

Holtsmark, B., 2012. Harvesting in boreal forests and the biofuel carbon debt. Clim. Change 112, 415-428.

Hudiburg, T.W., Law, B.E., Wirth, C., Luyssaert, S., 2011. Regional carbon dioxide implications of forest bioenergy production. Nature Clim. Change 1, 419-423.

Hungate, B.A., Dukes, J.S., Shaw, M.R., Luo, Y., Field, C.B., 2003. Nitrogen and climate change. Science 302, 1512-1513.

Jackson, R.B., Jobbágy, E.G., Avissar, R., Roy, S.B., Barrett, D.J., Cook, C.W., Farley, K.A., Le Maitre, D.C., McCarl, B.A., Murray, B.C., 2005. Trading water for carbon with biological carbon sequestration. Science 310, 1944-1947.

Jactel, H., Nicoll, B.C., Branco, M., Gonzalez-Olabarria, J.R., Grodzki, W., Långström, B., Moreira, F., Netherer, S., Orazio, C., Piou, D., et al., 2009. The influences of forest stand management on biotic and abiotic risks of damage. Ann. For. Sci. 66, 1-18.

Janssens, I.A., Dieleman, W., Luyssaert, S., Subke, J.-A., Reichstein, M., Ceulemans, R., Ciais, P., Dolman, A.J., Grace, J., Matteucci, G., et al., 2010. Reduction of forest soil respiration in response to nitrogen deposition. Nat. Geosci. 3, 315-322.

Johnson, E., 2009. Goodbye to carbon neutral: Getting biomass footprints right. Environ. Impact Assess. Rev. 29, 165-168.

Jones, C.D., Cox, P., Huntingford, C., 2003. Uncertainty in climate-carbon-cycle projections associated with the sensitivity of soil respiration to temperature. Tellus B 55, 642-648.

Kaipainen, T., Liski, J., Pussinen, A., Karjalainen, T., 2004. Managing carbon sinks by changing rotation length in European forests. Environ. Sci. Policy 7, 205-219.

Kallio, A.M.I., Salminen, O., Sievänen, R., 2013. Sequester or substitute-consequences of increased production of wood based energy on the carbon balance in Finland. J. For. Econ. 19, 402-415.

Kurz, W.A., Dymond, C.C., Stinson, G., Rampley, G.J., Neilson, E.T., Carroll, A.L., Ebata, T., Safranyik, L., 2008. Mountain pine beetle and forest carbon feedback to climate change. Nature 452, 987-990.

Landmann, G., Nivet, C., 2014. Projet Resobio. Gestion des rémanents forestiers: préservation des sols et de la biodiversité. Ministère de l'agriculture, de l'agroalimentaire et de la forêt - GIP Ecofor, Angers : ADEME.

Le Quéré, C., Raupach, M.R., Canadell, J.G., Marland, G., Bopp, L., Ciais, P., Conway, T.J., Doney, S.C., Feely, R.A., Foster, P., 2009. Trends in the sources and sinks of carbon dioxide. Nat. Geosci. 2, 831-836.

Lévesque, M., Saurer, M., Siegwolf, R., Eilmann, B., Brang, P., Bugmann, H., Rigling, A., 2013. Drought response of five conifer species under contrasting water availability suggests high vulnerability of Norway spruce and European larch. Glob. Change Biol. 19, 3184-3199.

Lewis, S.L., Lopez-Gonzalez, G., Sonké, B., Affum-Baffoe, K., Baker, T.R., Ojo, L.O., Phillips, O.L., Reitsma, J.M., White, L., Comiskey, J.A., 2009. Increasing carbon storage in intact African tropical forests. Nature 457, 1003-1006.

Lindenmayer, D.B., Noss, R.F., 2006. Salvage logging, ecosystem processes, and biodiversity conservation. Conserv. Biol. 20, 949-958.

Lindner, M., Fitzgerald, J.B., Zimmermann, N.E., Reyer, C., Delzon, S., van der Maaten, E., Schelhaas, M.-J., Lasch, P., Eggers, J., van der Maaten-Theunissen, M., et al., 2014. Climate change and European forests: What do we know, what are the uncertainties, and what are the implications for forest management? J. Environ. Manage. 146, 69-83.

Lindroth, A., Lagergren, F., Grelle, A., Klemedtsson, L., Langvall, O.L.A., Weslien, P.E.R., Tuulik, J., 2009. Storms can cause Europe-wide reduction in forest carbon sink. Glob. Change Biol. 15, 346-355.

Lippke, B., Oneil, E., Harrison, R., Skog, K., Gustavsson, L., Sathre, R., 2011. Life cycle impacts of forest management and wood utilization on carbon mitigation: knowns and unknowns. Carbon Manage. 2, 303-333.

Liski, J., Pussinen, A., Pingoud, K., Mäkipää, R., Karjalainen, T., 2001. Which rotation length is favourable to carbon sequestration? Can. J. For. Res. 31, 2004-2013.

Liu, G., Han, S., 2009. Long-term forest management and timely transfer of carbon into wood products help reduce atmospheric carbon. Ecol. Model. 220, 1719-1723.

Lundmark, T., Bergh, J., Hofer, P., Lundström, A., Nordin, A., Poudel, B.C., Sathre, R., Taverna, R., Werner, F., 2014. Potential roles of swedish forestry in the context of climate change mitigation. Forests 19994907, 5.

Luyssaert, S., Ciais, P., Piao, S.L., Schulze, E.-D., Jung, M., Zaehle, S., Schelhaas, M.J., Reichstein, M., Churkina, G., Papale, D., et al., 2010. The European carbon balance. Part 3: forests. Glob. Change Biol. 16, 1429-1450.

Luyssaert, S., Inglima, I., Jung, M., Richardson, A.D., Reichstein, M., Papale, D., Piao, S.L., Schulze, E.-D., Wingate, L., Matteucci, G., et al., 2007. $\mathrm{CO}_{2}$ balance of boreal, temperate, and tropical forests derived from a global database. Glob. Change Biol. 13, 2509-2537.

Luyssaert, S., Schulze, E.-D., Börner, A., Knohl, A., Hessenmöller, D., Law, B.E., Ciais, P., Grace, J., 2008. Old-growth forests as global carbon sinks. Nature 455, 213-215. 
Mack, M.C., Schuur, E.A., Bret-Harte, M.S., Shaver, G.R., Chapin, F.S., 2004. Ecosystem carbon storage in arctic tundra reduced by long-term nutrient fertilization. Nature 431, 440-443.

Magnani, F., Mencuccini, M., Borghetti, M., Berbigier, P., Berninger, F., Delzon, S., Grelle, A., Hari, P., Jarvis, P.G., Kolari, P., 2007. The human footprint in the carbon cycle of temperate and boreal forests. Nature 447, 849-851.

Marland, G., Schlamadinger, B., 1997. Forests for carbon sequestration or fossil fuel substitution? A sensitivity analysis. Biomass Bioenergy 13, 389-397.

Martin, T.J., Ogden, J., 2006. Wind damage and response in New Zealand forests: a review. New Zealand J. Ecol. 295-310.

McIver, J.D., Starr, L., Portland, O., et al., 2000. Environmental Effects of Postfire Logging: Literature Review and Annotated Bibliography. US Dept. of Agriculture, Forest Service, Pacific Northwest Research Station, Portland, Or.

McMahon, S.M., Parker, G.G., Miller, D.R., 2010. Evidence for a recent increase in forest growth. Proc. Nat. Acad. Sci. USA 107, 3611-3615.

Milne, R., Van Oijen, M., 2005. A comparison of two modelling studies of environmental effects on forest carbon stocks across Europe. Ann. For. Sci. 62, 911-923.

Mitchell, S.J., 2012. Wind as a natural disturbance agent in forests: a synthesis. Forestry cps058.

Nabuurs, G.-J., Lindner, M., Verkerk, P.J., Gunia, K., Deda, P., Michalak, R., Grassi, G., 2013. First signs of carbon sink saturation in European forest biomass. Nature Clim. Change 3, 792-796.

Nabuurs, G.J., Päivinen, R., Schanz, H., 2001. Sustainable management regimes for Europe's forests-a projection with EFISCEN until 2050. Forest Policy Econ. 3, 155-173.

Nabuurs, G.-J., Schelhaas, M.-J., Field, C.B., et al., 2003. Temporal evolution of the European forest sector carbon sink from 1950 to 1999. Glob. Change Biol. 9, $152-160$

Naudts, K., Ryder, J., McGrath, M.J., Otto, J., Chen, Y., Valade, A., Bellasen, V., Berhongaray, G., Bönisch, G., Campioli, M., et al., 2015. A vertically discretised canopy description for ORCHIDEE (SVN r2290) and the modifications to the energy, water and carbon fluxes. Geosci. Model Develop. 8, 2035-2065.

Norby, R.J., Warren, J.M., Iversen, C.M., Medlyn, B.E., McMurtrie, R.E., 2010. $\mathrm{CO}_{2}$ enhancement of forest productivity constrained by limited nitrogen availability. Proc. Nat. Acad. Sci. USA 107, 19368-19373.

Odum, E.P., 1969. The strategy of ecosystem development. Sustain.: Sustain. 164, 58.

Pan, Y., Birdsey, R.A., Fang, J., Houghton, R., Kauppi, P.E., Kurz, W.A., Phillips, O.L., Shvidenko, A., Lewis, S.L., Canadell, J.G., et al., 2011. A large and persistent carbon sink in the world's forests. Science 333, 988-993.

Penman, J., Gytarsky, M., Hiraishi, T., Krug, T., Kruger, D., Pipatti, R., Buendia, L., Miwa, K., Ngara, T., Tanabe, K., et al., 2003. Good Practice Guidance for Land Use, Land-use Change and Forestry. Institute for Global Environmental Strategies.

Perez-Garcia, J., Lippke, B., Comnick, J., Manriquez, C., 2007. An assessment of carbon pools, storage, and wood products market substitution using life-cycle analysis results. Wood Fiber Sci. 37, 140-148.

Pilli, R., Grassi, G., Kurz, W.A., Fiorese, G., Cescatti, A., 2017. The European forest sector: past and future carbon budget and fluxes under different management scenarios. Biogeosciences 14, 2387.

Poudel, B.C., Sathre, R., Bergh, J., Gustavsson, L., Lundström, A., Hyvönen, R., 2012 Potential effects of intensive forestry on biomass production and total carbon balance in north-central Sweden. Environ. Sci. Policy 15, 106-124.

Pretzsch, H., Schütze, G., Uhl, E., 2013. Resistance of European tree species to drought stress in mixed versus pure forests: evidence of stress release by inter-specific facil itation. Plant Biol. 15, 483-495.

Profft, I., Mund, M., Weber, G.-E., Weller, E., Schulze, E.-D., 2009. Forest management and carbon sequestration in wood products. Europ. J. For. Res. 128, 399-413.

Ragauskas, A.J., Williams, C.K., Davison, B.H., Britovsek, G., Cairney, J., Eckert, C.A., Frederick, W.J., Hallett, J.P., Leak, D.J., Liotta, C.L., et al., 2006. The path forward for biofuels and biomaterials. Science 311, 484-489.

Raich, J.W., Nadelhoffer, K.J., 1989. Belowground carbon allocation in forest ecosystems: global trends. Ecology 70, 1346-1354.

Ryan, M.G., Binkley, D., Fownes, J.H., 1997. Age-related decline in forest productivity: pattern and process. Adv. Ecol. Res. 27, 213-262.

Sathre, R., O'Connor, J., 2010. Meta-analysis of greenhouse gas displacement factors of wood product substitution. Environ. Sci. Policy 13, 104-114.

Schütz, J.-P., Götz, M., Schmid, W., Mandallaz, D., 2006. Vulnerability of spruce (Picea abies) and beech (Fagus sylvatica) forest stands to storms and consequences for silviculture. Eur. J. Forest Res. 125, 291-302.

Seidl, R., Schelhaas, M.-J., Lexer, M.J., 2011. Unraveling the drivers of intensifying forest disturbance regimes in Europe. Glob. Change Biol. 17, 2842-2852.

Sievänen, R., Salminen, O., Lehtonen, A., Ojanen, P., Liski, J., Ruosteenoja, K., Tuomi, M., 2014. Carbon stock changes of forest land in Finland under different levels of wood use and climate change. Ann. For. Sci. 71, 255-265.

Singh, B.K., Bardgett, R.D., Smith, P., Reay, D.S., 2010. Microorganisms and climate change: terrestrial feedbacks and mitigation options. Nat. Rev. Microbiol. 8 , 779-790.

Smith, P., Davis, S.J., Creutzig, F., Fuss, S., Minx, J., Gabrielle, B., Kato, E., Jackson, R.B., Cowie, A., Kriegler, E., et al., 2016. Biophysical and economic limits to negative $\mathrm{CO}_{2}$ emissions. Nature Clim. Change 6, 42-50.

Smyth, C.E., Stinson, G., Neilson, E., Lemprière, T.C., Hafer, M., Rampley, G.J., Kurz, W.A., 2014. Quantifying the biophysical climate change mitigation potential of Canada's forest sector. Biogeosciences 11, 3515-3529.

Solberg, S., Dobbertin, M., Reinds, G.J., Lange, H., Andreassen, K., Fernandez, P.G., Hildingsson, A., de Vries, W., 2009. Analyses of the impact of changes in atmospheric deposition and climate on forest growth in European monitoring plots: a stand growth approach. For. Ecol. Manage. 258, 1735-1750.

Strömgren, M., Egnell, G., Olsson, B.A., 2013. Carbon stocks in four forest stands in Sweden 25 years after harvesting of slash and stumps. For. Ecol. Manage. 290, 59-66.

Subke, J.-A., Bahn, M., 2010. On the 'temperature sensitivity'of soil respiration: can we use the immeasurable to predict the unknown? Soil Biol. Biochem. 42, 1653-1656.

Tang, J., Baldocchi, D.D., Xu, L., 2005. Tree photosynthesis modulates soil respiration on a diurnal time scale. Glob. Change Biol. 11, 1298-1304.

Tang, J., Luyssaert, S., Richardson, A.D., Kutsch, W., Janssens, I.A., 2014. Steeper declines in forest photosynthesis than respiration explain age-driven decreases in forest growth. Proc. Nat. Acad. Sci. USA 111, 8856-8860.

Trømborg, E., Sjølie, H.K., Bergseng, E., Bolkesjø, T.F., Hofstad, O., Rørstad, P.K., Solberg, B., Sunde, K., 2011. Carbon Cycle Effects of Different Strategies for Utilisation of Forest Resources - A Review. Department of Ecology and Natural Resource Management Norwegian University of Life Sciences.

UNFCCC, 2015. Adoption of the Paris agreement (No. FCCC/CP/2015/L.9/Rev.1:), Conference of the parties. UNFCCC, Paris.

Valinger, E., Fridman, J., 2011. Factors affecting the probability of windthrow at stand level as a result of Gudrun winter storm in southern Sweden. For. Ecol. Manage. 262, 398-403.

Van der Werf, G.R., Morton, D.C., DeFries, R.S., Olivier, J.G., Kasibhatla, P.S., Jackson, R.B., Collatz, G.J., Randerson, J.T., 2009. CO2 emissions from forest loss. Nat. Geosci. $2,737-738$.

Vandekerkhove, K., De Keersmaeker, L., Menke, N., Meyer, P., Verschelde, P., 2009. When nature takes over from man: Dead wood accumulation in previously managed oak and beech woodlands in North-western and Central Europe. For. Ecol. Manage. $258,425-435$.

Vanhala, P., Repo, A., Liski, J., 2013. Forest bioenergy at the cost of carbon sequestration? Curr. Opin. Environ. Sustain. 5, 41-46.

Von Storch, H., Zwiers, F.W., 2001. Statistical Analysis in Climate Research. Cambridge University Press, Cambridge.

Vörösmarty, C.J., Pahl-Wostl, C., Bhaduri, A., 2013. Water in the anthropocene: new perspectives for global sustainability. Curr. Opin. Environ. Sustain. 6, 535-538.

Wang, S., Zhou, L., Chen, J., Ju, W., Feng, X., Wu, W., 2011. Relationships between net primary productivity and stand age for several forest types and their influence on China's carbon balance. J. Environ. Manage. 92, 1651-1662.

Werner, F., Taverna, R., Hofer, P., Richter, K., 2006. Greenhouse gas dynamics of an increased use of wood in buildings in Switzerland. Clim. Change 74, 319-347.

Zeng, H., Chambers, J.Q., Negrón-Juárez, R.I., Hurtt, G.C., Baker, D.B., Powell, M.D. 2009. Impacts of tropical cyclones on US forest tree mortality and carbon flux from 1851 to 2000. Proc. Nat. Acad. Sci. USA 106, 7888-7892.

Zubizarreta-Gerendiain, A., Pukkala, T., Peltola, H., 2016. Effects of wood harvesting and utilisation policies on the carbon balance of forestry under changing climate: a Finnish case study. For. Policy Econ. 62, 168-176. 